\title{
BIOSYNTHESIS OF CELLULASE PROTEIN FROM CHEAPER SUBSTRATES USING MIXED CULTURE OF TRICHODERMA REESEI AND PENICILLIUM FUNICULOSUM - A NOVEL APPROACH
}

\author{
B. Bharathiraja ${ }^{1}$, J.Jayamuthunagai ${ }^{2}$, M. Jayakumar ${ }^{3}$ and N.Karmegam ${ }^{4}$ \\ ${ }^{1}$ Department of Biotechnology, Arunai Engineering College, India \\ ${ }^{2}$ Department of Chemical Engineering, Annamalai University, India \\ ${ }^{3}$ Arulmigu Meenakshi Amman College of Engineering, Vadamavandal, India. \\ ${ }^{4}$ Department of Biotechnology, V.M.K.V. Engineering College, India. \\ E-mail: btrbio@gmail.com;
}

\begin{abstract}
Plant cell wall degrading enzymes are given importance due to the development of efficient biomass degradation methods and the conversion of sugars to valuable products like butanol, amino acids and utilizable forms such as ethanol and methane. Plant biomass is an abundant renewable resource with cellulose and hemicellulose comprising about $40-50 \%$ of plant cell. The rate-limiting step in biomass degradation is the conversion of the cellulose and hemicellulose polymers to sugars. Cellulase enzyme has many potent commercial applications in industries. It is commonly produced as an extra cellular enzyme in fungi, bacteria and insects, however fungal enzymes are amongst the most extensively studied and characterized. Trichoderma reesei is the most commonly used organism for the commercial production of cellulase. An attempt has been made in the present study to improve the yield by using a mixed culture of Trichoderma reesei and Penicillium funiculosum on low cost substrates, corn fibre and sugarcane bagasse. The results show that the growth of $T$. reeseiand $P$. funiculosum, production rate and cellulase activity was high only when sugarcane bagasse was used as substrate than that of corn fibre. Also the yield of cellulase enzyme and its activity were greater in the case of mixed culture than pure cultures of T. reeseiand $P$. funiculosum.
\end{abstract}

KEY WORDS: Cellulose, Cellulase, Corn fibre, Growth kinetics and product kinetics, Sugarcane Bagasse, Trichoderma Peesei, Penicillum funiculosum.

\section{INTRODUCTION}

Enzymes are proteins that speed up biological reactions and the process of action by enzymes is referred as enzyme catalysis. Various classification systems have evolved based on substrate used or products formed. Presently, the enzymes are classified with six main categories. The present day classification system shares its rules with the nomenclature also, thus easing the process of identifying a particular enzyme. They are classified as oxidoreductase, transferases, hydrolases, lyases, isomerases and ligases. Cellulases are the enzymes capable of degrading polysaccharides, which are chemically simple polymers of repeating glucose units. A broad range of microbes produce cellulase (Table- 1). Among them, fungal cellulases have been studied extensively and are effectively used for commercial areas of application.

Table 1. Representation of various cellulase producing microorganisms

\begin{tabular}{|c|c|c|c|}
\hline & Microorganism & & Microorganism \\
\hline \multirow{16}{*}{ Fungi } & Aspergillus acculeatus & \multirow{6}{*}{ Bacteria } & Clostridium thermocellum \\
\hline & Aspergillus fumigatus & & Ruminococcus albus \\
\hline & Acremonium cellulolyticus & & \multirow[t]{4}{*}{ Streptomyces spp. } \\
\hline & Fusarium solani & & \\
\hline & Irpex lacteus & & \\
\hline & Penicillum funiculosum & & \\
\hline & Phanerochaete & \multirow{10}{*}{ Actinomycetes } & Streptomyces spp. \\
\hline & Chrysosporium & & Thermosctinomyces spp. \\
\hline & Schizophyllum commune & & \multirow[t]{8}{*}{ Thermomonospora curvata } \\
\hline & Sclerotium rolfsii & & \\
\hline & Sporotrichum cellulophilum & & \\
\hline & Talaromyces emersonii & & \\
\hline & Thielavia terrestris & & \\
\hline & Tricoderma koningii & & \\
\hline & Trichoderma reesei & & \\
\hline & Trichoderma viride & & \\
\hline
\end{tabular}


Production of industrial enzymes including Cellulases requires minimum cost with the downstream processing [1]. During the search for hypercellulolytic micro organisms, ultraviolet irradiation carried out with Penicillium funiculosum yielded a superior mutant enzyme [7]. Agricultural wastes such as corncob, wheat bran were found suiTable- for production of cellulase [21, 30]. Large quantities of cellulosic waste are produced and dumped in landfills every year by the meat processing industry worldwide. This waste can be categorized as organic waste and can be easily utilized for the production of beneficial byproducts for the food industry [8]. The properties of cellulase are as follows.

\section{A. Cellulase-binding domains or CBD}

These domains are responsible for bringing the molecule in position with respect to the cellulose molecule. CBD's are usually located either in the $\mathrm{N}$ or $\mathrm{C}$ terminals of the protein. Although internal functional CBD's also exist.

\section{B. Catalytic core}

This is the area where cellulose is broken down. The catalytic domain has $\alpha / \beta$ barrel fold. Two sTable- surface loops generate a $20 \AA$ long tunnel for substrate binding a catalyst. The active site tunnel contains four defined binding sites (A-D) from glycoside units. In the sites $A, C$ and $D$, sugar binding is characterized by hydrophobic interactions of the glucoside units with W135 (A), W269(C) and W367 (D). At the entrance of the active site tunnel, W272 apparently gives rise to favourable stacking interactions with the sixth glucosyl unit. This site is referred to as putative binding site $F$.

\section{Flexible and heavily glycosylated linker regions}

It guides the CBD and the core over the substrate. The linkers are rich in glycine, proline, serine and threonine residues and O-glycosylated. The cellobiohydrolase enzyme mainly cleaves the glycosylic linkage by general acid catalysis. Three amino acids in the active site play an important role - Tyrosine residue (Y169), Tryptophan residue (W135), Tryptophan residue (W272). These are three different types of Cellulases, the endoglucanases, exoglucanases, and $\beta$-glycosidase. The cellulase complex enzyme is tightly regulated to ensure that cellulosedegrading fungus does not release sugars at a faster rate than it can use them. The regulation of cellulose breakdown is also achieved in common feedback systems termed catabolic repressions.

Most Cellulases studied have similar pH optima, solubility and amino acid composition whereas thermal stability and exact substrate specificity may vary. The cellulase complexes have some distinct characteristic features. They are multi enzymatic, the three enzyme components are both physically and enzymatically distinct, and all three components play essential roles in the overall process of converting cellulose to glucose $[2,4]$.

The optimum pH generally lies between 4.2 and 5.2 . The optimum temperature range is $40^{\circ} \mathrm{C}-50^{\circ} \mathrm{C}$. The activity of cellulase preparations has been found to be completely destroyed after $10-15$ minutes at $80^{\circ} \mathrm{C}$. Solutions of cellulase at pH 5-7 are sTable- for 24 hours at $4^{\circ} \mathrm{C}$. These products should be stored at $4^{\circ} \mathrm{C}$, in a dry place and tightly closed containers. If stored in this manner, lyophilized preparations are sTable- for several months without significant loss of activity. Cellulases are able to decompose natural cellulose as well as modified cellulose. The cellulose substrates used in the present study were corn fibre and sugar cane bagasse and their composition are shown in Table-s 2 and 3.

\section{Table 2. Composition of cellulosic biomass used in the study.}

\begin{tabular}{|l|l|l|l|l|}
\hline Cellulosic Biomass & $\begin{array}{l}\text { Cellulose } \\
(\%)\end{array}$ & $\begin{array}{l}\text { Hemicelluloses } \\
(\%)\end{array}$ & $\begin{array}{l}\text { Lignin } \\
(\%)\end{array}$ & $\begin{array}{l}\text { Ash } \\
(\%)\end{array}$ \\
\hline $\begin{array}{l}\text { Sugarcane } \\
\text { Bagasse }\end{array}$ & 60 & 15 & 23 & 2 \\
\hline Corn Fibre & 45 & 25 & 6 & 8 \\
\hline
\end{tabular}

Table 3. Chemical composition of sugarcane bagasse

\begin{tabular}{|l|l|}
\hline Contents & Amount(g/l) \\
\hline Total reducing sugars & 70.9 \\
\hline Xylose & 25.2 \\
\hline Glucose & 41.0 \\
\hline Fermentable reducing sugar & 44.6 \\
\hline $\begin{array}{l}\text { Non- fermentable reducing } \\
\text { sugar }\end{array}$ & 26.3 \\
\hline Lignin & 23.0 \\
\hline Ash & 1.1 \\
\hline Moisture & 47.8 \\
\hline
\end{tabular}

Pre-treatment of cellulosic biomass in a cost-effective manner is a major challenge of cellulose- ethanol technology research and development [11]. It is important to pretreat the cellulosic biomass prior to use it as substrate. Pre treatment increases the crystallinity of cellulose, while removing lignin and other inhibitors, thereby enabling its enzymatic degradation. In addition, pre-treatment may increase the surface area of the cellulose thereby enhancing its reactivity with the enzyme and thus its transformation. 
The enzymatic mechanism whereby certain micro organisms can quiet rapidly and completely degrade cellulose is not yet understood. It is proposed that at least two steps are involved [19].

a. Pre-hydrolytic step wherein hydroglucose chains are swollen or hydrated thereby decrystalizing the highly ordered crystalline cellulose. This would involve the enzyme C1.

b. Hydrolytic cleavage of the now susceptible soluble polymers either randomly or end wise. This would mean the hydrolytic enzyme termed $C_{c}$. itconsists of exo and endo $\beta$ 1,4 glucanases.

The commercial use of cellulase is dependent on high titter and good enzymatic activity, low production cost and feasible mass production.

Cellulase is used for commercial food processing in coffee. It performs hydrolysis of cellulose drying of beans [12]. Cellulose is used in the conversion of biomass in to biofuel although this process is relatively experimental at procedure $[5,8]$. Cellulase enzyme is used in food industry for preparing juices and to increase yield. By the use of thermophilic cellulase, it is possible to prevent contamination as the juicing process can be performed at higher temperatures $[9,15,18,28]$. Traditionally the juice was prepared by crushing the apples and then filtering the juice, which resulted in poor yield. But at present cellulases are added after crushing, to the leftover pulp and thereby yield is dramatically increased. Using in detergents helps to clean the fuzzy looks in the robes. It helps to keep the colour brightness and also to keep the cloth fibre as brand as new. Paper is made from cellulose fibres that must be separated from a tough wood fibre called lignin by a process known as pulping. In bio-pulping cellulases are used to pretreat wood and break down the lignin fibres. It is the strength of the fibre. Most recent usage of cellulase in the production of ethanol for fuel has lead to decrease the production of carbon dioxide by $90 \%$ in the fuels [5]. Also used in the cotton pre-treatment in the textile industries [10]

\section{MATERIALS AND METHODS}

\section{A.Maintenance of Sub-culture:}

Pure cultures of Trichoderma reesei and Penicillium funiculosum were obtained from MTCC and sub-cultured on malt extract slants. The streaked culture from mother culture were on malt extract agar slants, were incubated at $37^{\circ} \mathrm{C}$ for 5 days. After sufficient growth of culture, they were refrigerated at $4^{\circ} \mathrm{C}$ for further use by regular sub-culturing.

\section{B.Pretreatment Method Employed:}

Before the fermentation process the substrate was pre treated to separate one or more of the biomass components- hemi-cellulose, cellulose, lignin and other extractives. Pre-treatment is generally done for further biological treatment by the mixed culture of $T$. reesei and $P$. funiculosum.

Alkaline pre-treatment method was carried out. $100 \mathrm{~g}$ sugarcane bagasse and corn fibre were separately treated with $2000 \mathrm{ml}$ of $4 \%$ aqueous $\mathrm{NaOH}$ solution, then autoclaved at $121^{\circ} \mathrm{C}$ for 30 minutes. The contents were filtered and washed with distilled water until neutrality, and dried at $65^{\circ} \mathrm{C}$ to constant weight. Dried portion was neutralized with phosphoric acid and filtered. The substrate was recovered and dried at $65^{\circ} \mathrm{C}$ to constant weight, then autoclaved second time for 30 minutes at $121^{\circ} \mathrm{C}$ with equal volume of distilled water.

\section{C.Fermentation Process:}

Fermentation was carried out in seven different conical flasks labelled A-F for 1- 7 days and assayed respectively. The production media was prepared and autoclaved at $121^{\circ} \mathrm{C}$ for 20 minutes. $100 \mathrm{ml}$ of production media was poured into each flask. pH was maintained at 6.5 in each flask. Flasks were inoculated with mixed culture of $T$. reesei and $P$. funiculosum in the ratio1:1 and incubated at $30^{\circ} \mathrm{C}$ in shaking incubator and assayed at corresponding time intervals.

\section{D.Assay Procedure:}

\section{Estimation of biomass}

For the estimation of biomass, $5 \mathrm{ml}$ culture broth was centrifuged at 1000rpm for 20 minutes in pre-weighed centrifuge tube. The supernatant was discarded. The resulting pellet was dried and dry weight was estimated.

\section{Estimation of reducing sugar}

Reducing sugar was estimated by DNS (Dinitro Salicylic acid) method. The sugars in the sample were extracted using $80 \%$ hot ethanol twice with $5 \mathrm{ml}$ of sample. After the extract was collected, it was evaporated by keeping it in water bath at $80^{\circ} \mathrm{C}$, the sugars settle at the bottom. The settled sugars were dissolved with $10 \mathrm{ml}$ of water. To this unknown sugar solution, the DNS procedure was carried out and the samples were read calorimetrically at $510 \mathrm{~nm}$. Glucose was used for obtaining the standard calibration curve. By interpolation, the concentration of unknown sugar solution was determined. (Sadasivam, 2005)

\section{Estimation of proteins}

For determining the protein concentration in the cultured sample, Lowry's method was used. For the extraction of proteins, $5 \mathrm{ml}$ of sample was taken and $5 \mathrm{ml}$ $10 \mathrm{ml}$ of buffer was added and centrifuged. The supernatant 
was used for protein estimation. Lowry's method was carried out with the supernatant samples and read calorimetrically at $660 \mathrm{~nm}$. Solution of bovine serum albumin was used for obtaining the standard calibration curve. With this curve as reference, the proteins in the sample was further determined. (Sadasivam, 2005)

\section{Estimation of cellulase concentration}

The procedure followed for the estimation of cellulase activity was using the enzyme extract. $0.5 \mathrm{ml}$ of enzyme extract was added to $32 \mathrm{mg}$ of dry Whatman No.1 filter paper. The mixture was incubated at $50^{\circ} \mathrm{C}$ for $1 \mathrm{hr}$. After the removal of enzyme substrate complex from the water bath $0.5 \mathrm{ml}$ of DNS reagent was added. The mixture was heated in warm with boiling water bath for $5 \mathrm{~min}$. One $\mathrm{ml}$ of potassium sodium tartarate solution was added with warm solution in respective tubes then cooled to room temperature. Finally the volume was made to $5 \mathrm{ml}$ using distilled water. The prepared samples were biospectroscopically read at $540 \mathrm{~nm}$. Glucose was used for preparation of standard calibration curve. Enzyme activity was reported in $\mathrm{mg}$ glucose released $/ \mathrm{min} / \mathrm{mg}$ protein. ( Sadasivam , 2005)

\section{RESULTS AND DISCUSSIONS}

Biomass, reducing sugar, amount of protein and cellulase activity is shown in Figs. 1,2 and 3 respectively. Pre-treated substrates contain large amount of cellulose. Cellulose is a polysaccharide, thus it requires more time. Based on the assays performed for substrate biomass protein and cellulase activity, the results can be tabulated for both sugarcane bagasse and corn fibre.

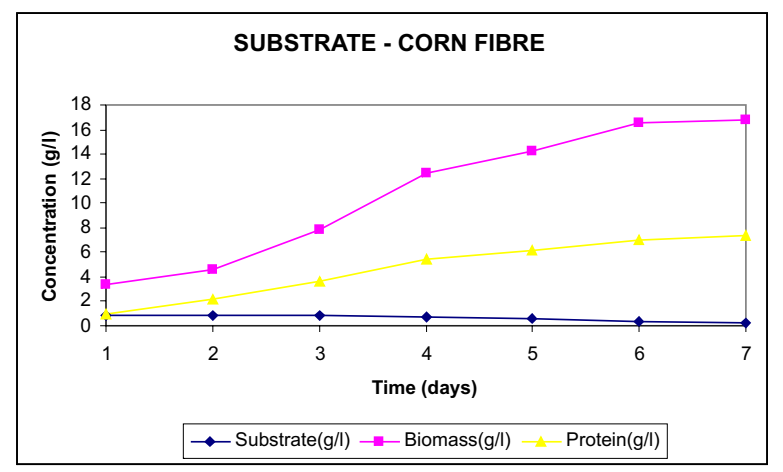

Fig. 1. Effect of cellulase concentration on corn fibre as substrate

On comparing the cellulase activity on both substrates, the graph was obtained as below.

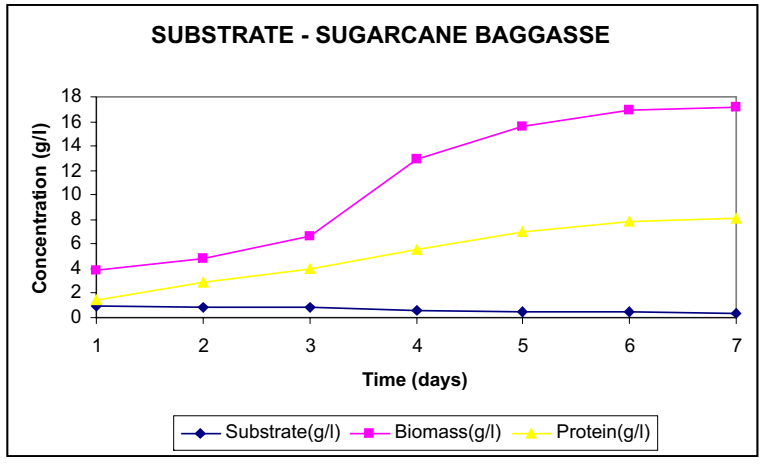

Fig. 2. Effect of cellulase concentration on sugarcane bagasse as substrate

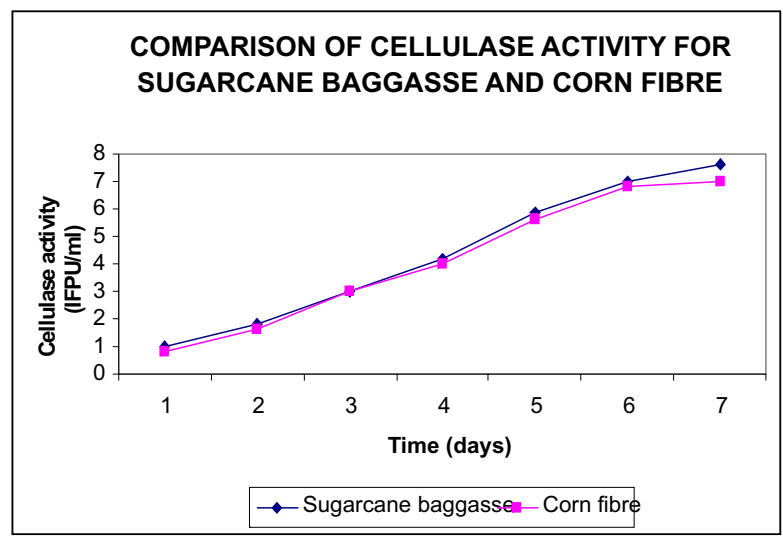

Fig. 3. Comparative analysis for sugarcane bagasse and corn fibre (cellulase activity)

\section{A. KINETICS ESTIMATION:}

Growth kinetics and production kinetics were developed for the fermentation carried out at $30^{\circ} \mathrm{C}$ and $\mathrm{pH} 6.5$.

\section{GROWTHKINETICS:}

The growth kinetics was done using Monod's kinetic model. The graph was plotted between time versus biomass concentration and spent growth rate was obtained by taking slopes to the curve at various points. Specific growth rate $(\mu)=(1 / x)(d p / d t)$. The graph was plotted between $(1 / \mu)$ and $(1 / s)$. [Fig. 4] from the graph the intercept (1/ $\mu$ max $)$ and slope (Ks/ $\mu$ max) was found.

The specific growth rate was 0.888 Day- 1 and Monod constant (Ks) was $1.372 \mathrm{~g} / \mathrm{l}$ for sugarcane bagasse. In a similar way it is also calculated for corn fibre. The specific growth rate was 0.454 Day-1 and Monod constant (Ks) was $1.136 \mathrm{~g} / \mathrm{l}$ were found out.

\section{PRODUCTION KINETICS:}

Two kinetics models were used for this purpose - they are Michaelis Menten and Leudeking Piret kinetics. The 
results were tabulated.

\section{Michaelis Menten kinetics method}

The graph was plotted between $1 /[\mathrm{v}]$ and $1 /[\mathrm{s}]$. [Fig. 1] The slope (Km/Vmax) and intercept (1/ Vmax) as found out. The maximum production rate (Vmax) for sugarcane bagasse was calculated to be $5.88 \mathrm{~g} / \mathrm{l}$ day and Michaelis Menten constant $\mathrm{Km}$ was found to be $1.0875 \mathrm{G}[\mathrm{S}] / \mathrm{I}$. In the case of corn fibre the maximum production rate $\left(V_{\max }\right)$ is $4.34 \mathrm{~g} / \mathrm{l}$ day and the Michaelis Menten constant $(\mathrm{Km})$ is $1.0859 \mathrm{G}[\mathrm{S}] /$.

\section{Leudeking Piret kinetics method}

$$
d p / d t=a(d x / d t)+\beta x
$$

The graph was plotted between the product concentration and time. The slopes (dp/dt) at various points were found out. The values (dx/dt) were found out from the slopes at various points from the cell concentration curve. Now the graph was plotted between $((1 / x)(d p / d t))$ and $(1 / x)(d x / d t)$. [Fig. 5]. The intercept $\alpha=0.233$ and $\beta=0.042$ for Sugar cane bagasse were found out. For corn fibre $\alpha=$ 0.012 and $\beta=0.05$ were also found out.

\section{CONCLUSION}

The results obtained in the present study showed that the production of enzyme cellulase on the raw materials, sugar cane bagasse and corn fibre using mixed culture of $T$. reesei and $P$. funiculosum. As an inference, it is clear from the results that, the growth, production rate and cellulase activity were high only with sugarcane bagasse as substrate than corn fibre since sugarcane bagasse has high cellulose content. Also, from the nature of cellulase, an inducible enzyme, produced in higher amounts only when the substrate was highly rich in cellulose content. The yield of cellulase enzyme and its activity was greater in the case of mixed culture rather than when pure culture was used. However, the increase in the yield of cellulase can be only obtained by optimizing the culturing and fermentation parameters like - pH, temperature and innoculum size and substrate optimization with reference to the mixed culture. While opting for the mixed culture production of enzyme cellulase, the interaction natures like antagonistic activity involved between both strains too play a vital role in the selection of microorganisms. If the further success in cellulase production using mixed culture is brought, it would be the boom for the production of ethanol/biofuel using cellulose as substrate.

\section{ACKNOWLEDGEMENT}

I express my heartful thanks to our chairman Thiru.E.V.Velu (Food Minister Tamilnadu) who has provided with all the necessary organization, personel, equipment and infrastructure and who evinced keen interest and encouraged us throughout the successful completion of this work.

\section{REFERENCES}

[1] Avelino, S., Azzoni, A.R., Rosa, P.T., Miranda, E.A., and Santana, C.C., 1999. Recovery of cellulase by HPMC-salt precipitation: analysis by statistical experimental design. Appl Biochem Biotechnol. 7779: 807-815

[2] Beldman, G., Searle-van Leeuween, M., Rombouts, F., and Voragen, F.G.J., 1985. The cellulase of Trichoderma viride - Purification, characterization and comparison of all detecTable- endoglucanases, exoglucanases and $\beta$ - glucosidases. Eur J Biochem. $146: 301-308$

[3] Berg, R., Erdos, G., Gritzali, M., and Brown, R., 1987. Enzyme - Gold affinity labelling of Cellulose, J Electron Micr Tech 8 : 371

[4] Berghem, I., and Pettersson, L., 1973. The mechanism of enzymatic cellulose degradation. Purification of a cellulytic enzyme from Trichoderma viride active on highly ordered cellulose. Eur $\mathrm{J}$ Biochem, $37: 21$

[5] Bhat, M.K., 2000. Cellulases and Related enzymes in biotechnology. Biotechnol Advances 18:355383

[6] Brant, A., Hole, A., Cannon, J., Helm, J., Swales, C., Welch, J., Newman Taylor, A., and Cullinan, P., 2004. Occupational asthma caused by cellulase and lipase in detergent industry. Occupat Environ Medicine 61: 793-795

[7] Chandhuri, B.K., and Vikram Sahai, 1993. Production of cellulase using a mutant strain of Trichoderma reesei growing on lactose in batch culture. Appl Microbiol Biotechnol. 39 194-196

[8] Chapin III, F.S., Matson, P.A., Mooney,H.A.,2002.Principles of terrestrial ecosystem ecology. Springer-Verlag NY

[9] Crennell, S.J., Hreggvidsson, G.O., Karisson, E.N., 2002. The structure of Rhodothermus marinus cell2A, A highly thermosTable- family 12 Endoglucanase. J Mol Biol, 320 : 883-897

[10] Csiszar,E.,Losonczi,A.,Szakacs, G., Rusznak, I., Bezur, L., and Reicher, J., 2001. Enzymes and chelating agent in cotton pretreatment. J Biotechnol. $89: 271-279$ 
[11] Emert, G., Gum, E., Lang, J., Liu, T., and Brown, R., 1974. Cellulases, Food related enzymes. J. Whitaker, Amer. Chem. Soc., Washington DC, USA

[12] Haki, G.D., Rakshit, S.K., 2003. Developments in industrially important therosTable- enzymes: A Review. Bioresour Rev. 89: 17-34.

[13] Harvey, W.F., and John, U.L., 2000. Phytosterols in the aleurone layer of Corn kernels. Biochem. Soc. Trans. 28: 803-806

[14] Hirvonen, M., Papageorgiou, A.C., 2003. Crystal structure of the family 45 endoglucanases from Melanocarpus albomyces: Mechanist implications based on the free and cellobiose-bound forms. J. Mol. Biol. 329:403-410

[15] Hreggvidsson, G.O., Kaiste, E., Holst, O., Eggertsson, G., Palsdottier, A., Kristjansson, J.K., 1996. An extremely thermosTable- cellulose from the thermophilic eubacterium Rhodothermus marinus. Appl Environmen Microbiol. 62(8): 3047-3049

[16] Kanda, T., Wakabayashi, K., Nisizawa, K., 1980.Modes of Action of Exo and Endo cellulases in the degradation of celluloses I and II J Biochem (Tokyo), 87(6): 1635-1639

[17] Li, P.J., Jing, D.B., Zhou, Q.X., Zhang, C.G., 2004.Optimization of Solid Fermentation of Cellulase from Trichoderma konningi. J Environ Sci (China) 16(5) : 816-820

[18] Lo, C.M., Zhang, Q., Lee, P., Ju.L.K.,2005. Cellulase production by Trichoderma reesei using saw dust hydrolysate. Appl Biochem Biotechnol 121 - 124: $561-573$

[19] Myers, F.L., and Northcote, D.H, 1959 partial purification and some properties of a cellulase from helix pomatia. Biochem J, 71 : 749-756
[20] Hashimoto, Y., 1959. Cellulase splitting enzymes Difference in specificity of cellulose and $\beta$ glucosidases from Irpex lacteus. Arch. Biochem. Biophys, $81: 211-222$.

[21] Okada, G., Nisizawa, K., Suzuki, H., 1968. Cellulase components from Trichoderma viride. J. Biochem. (Tokyo) 63(5): 591-607

[22] Schaffher, D.W., and Toledo, R.T., 1990. Cellulase production by Trichoderma reesei when cultured on xylose-based media supplemented with sorbose. Biochem Bioengg. 37 : 12-16

[23] Schiraldi, C., De Rosa, M., 2002. The production of biocatalyst and Biomolecyle from extremophiles. Trends in biotechnology 20(12):515-521

[24] Tarun K Ghose, 1969. Continuous enzymatic saccharification of cellulose with culture filtrates of Trichoderma viride. Biotechnol Bioengg. 11: 239-261

[25] Vielle, C., Zeikus, G.J., 2001. Hyperthermophilic enzymes: sources, uses and molecular mechanisms for thermo stability. Microbiol Mol Biol Rev. 65(1) 1 34

[26] Wen, Z., Liao, W., Chen, S., 2005. Production of cellulase/ $\beta$-glucosidasesby mixed fungi culture of of Trichoderma reesei and Aspergillus phoenicis on dairy manure. Appl Biochem Biotechnol. 121-124 : 93-104

[27] Zhao, J., Li, X., Qu, Y., 2005. Application of enzymes in producing bleached pulp from wheat straw. Bioresour Technol. 97(13): 1470-1476.

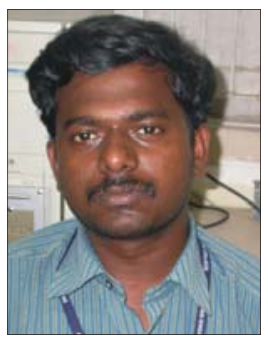

Mr.Bharathiraja.B is working in Arunai Enginnering College, Tiruvannamalai and simultaneously doing Ph.D in Anna University for past two years. He has 5 National and 1 International publications to his credit. 